\title{
Nothing lasts forever? Long-term outcomes of stress urinary incontinence surgery
}

\author{
Peter L. Dwyer
}

Published online: 25 April 2013

(C) The International Urogynecological Association 2013

One question every patient asks before surgery is "How long will this operation help?" Nothing lasts forever: this is true for a house you build, a car you run, or operations performed on your ageing body. So this is indeed a very good question, as every patient wants to have the best possible chance of a long-term cure for the condition they have surgery for. This is particularly true in disorders of the pelvic floor, with recent well-publicised studies suggesting up to a third of women need repeated surgery for pelvic organ prolapse and/or stress urinary incontinence [1]. It is our responsibility as their doctors to provide an honest answer to this question for our patients and to perform the most appropriate operation that not only has good safety and a satisfactory short-term outcome but also provides the patient with the best possible long-term cure. If an operation were to be performed on you or a member of your family, your interest in the 6- to 12-month result would be less than how well it was going to work 10 or 20 years down the line. Unfortunately long-term follow-up studies of surgery of any type are rare, and this is true for vaginal prolapse and urinary stress incontinence surgery. These procedures will never achieve $100 \%$ effectiveness, because the underlying causes for the disorders, such as damaged and ageing bladder and urethra, pelvic floor muscles and ligaments, are still present.

We have therefore selected as our Editors' Choice manuscript for this issue a study [2] by Nilsson et al. entitled "Seventeen years' follow-up of the tension-free vaginal tape procedure for female stress urinary incontinence". In this study the authors report that $48 / 55(87.2 \%)$ of the women regarded themselves cured or significantly better than before surgery. Objective cure, defined as a negative stress test, was seen in 42/46 women (91.3\%). Only one woman had a further stress incontinence procedure. In the following article

P. L. Dwyer $(\bowtie)$

Department of Urogynecology, Mercy Hospital for Women,

University of Melbourne, Melbourne, Australia

e-mail: pdwyer@connexus.net.au
Svenningsen et al [3] report a 10 year follow-up of TVT slings. Subjective and objective cure rates were high with $2.3 \%$ requiring repeat stress incontinence surgery. However de novo urge incontinence increased over the 10 years follow up to $15 \%$.

It is interesting to compare these studies to another 10- to 20-year follow-up study by Alcalay et al. [4] in 109 women who had a Burch colposuspension, which was also considered a gold standard procedure for USI in its time. They found that there was a decline in cure of incontinence following Burch colposuspension for 10-12 years, at which time a plateau of $69 \%$ is reached. In another long-term follow-up study of Burch colposuspension, Kjølhede [5] found that subjectively significant urinary incontinence was experienced by $56 \%$ of the 190 women 14 years after surgery. Only $19 \%$ reported no incontinence episodes, and leakage was present a few times a week $(13 \%)$ or daily (26\%). It is not possible to compare these studies' outcomes accurately as the criteria for success, and even the patient characteristics, vary. For instance, no women in the TVT group, but one in three women of the Burch group in the Alcalay study, had had previous incontinence surgery.

However, these studies provide valuable information to reassure our patients and set the bar for other procedures in terms of long-term effectiveness. In particular we need corresponding information on newer stress incontinence procedures such as the transobturator and single-incision mini-slings. These newer slings are now the most frequently employed by gynaecologists, but there is an urgent need for proof of long-term effectiveness if surgeons are to recommend and use these slings on patients.

Another article reporting longer-term outcomes is that by Funk et al. [6] entitled "Long-term outcomes of vaginal mesh versus native tissue repair for anterior vaginal wall prolapse". These authors found that the 5-year risk of surgery for recurrent prolapse was similar between vaginal mesh and native tissue groups (10.4\% vs. $9.3 \%, p=0.70)$ and another $5.9 \%$ had mesh revision/removal surgery over the 5 -year period. It 
is only over the long term that the worth or otherwise of surgery for pelvic floor dysfunction can be assessed.

The selection of Nilsson's article as Editor's Choice was also is in recognition of the long association of the International Urogynecology Journal (IUJ) with the TVT sling and the authors of the original studies of this operation. This procedure was first described in the IUJ in 1996 and the initial results presented in 1998 [7, 8], so it is appropriate for us to highlight this study reporting the 17-year results. The late Ulf Ulmsten was an Editor of the IUJ and Carl-Gustaf Nilsson is a longstanding and hard-working member of our Editorial Board. We recognise and congratulate them and the other authors on their fine contribution to urogynaecology.

\section{References}

1. Olsen AL, Smith VJ, Bergstrom JO, Colling JC, Clark AL (1997) Epidemiology of surgically managed pelvic organ prolapse and urinary incontinence. Obstet Gynecol 89:501-506
2. Nilsson CG, Palva K, Aarnio R, Morcos E, Falconer C (2013) Seventeen years' follow-up of the tension-free vaginal tape procedure for female stress urinary incontinence. Int Urogynecol J. doi:10.1007/s00192-013-2090-2

3. Svenningsen R, Staff AC, Schiøtz HA, Western K, KulsengHanssen S. Long-term follow-up of the retropubic tension-free vaginal tape procedure. Int Urogynecol J. doi:10.1007/s00192013-2058-2

4. Alcalay M, Monga A, Stanton SL (1995) Burch colposuspension: a 10-20 year follow up. Br J Obstet Gynaecol 102(9):740-745

5. Kjølhede P (2005) Long-term efficacy of Burch colposuspension: a 14-year follow-up study. Acta Obstet Gynecol Scand 84(8): $767-772$

6. Funk MJ, Visco AG, Weidner AC, Pate V, Wu JM (2013) Longterm outcomes of vaginal mesh versus native tissue repair for anterior vaginal wall prolapse. Int Urogynecol J. doi:10.1007/ s00192-013-2043-9

7. Ulmsten U, Henriksson L, Johnson P, Varhos G (1996) An ambulatory surgical procedure under local anesthesia for treatment of female urinary incontinence. Int Urogynecol J Pelvic Floor Dysfunct 7(2):81-85

8. Ulmsten U, Falconer C, Johnson P, Jomaa M, Lanner L, Nilsson CG et al (1998) A multicenter study of tension-free vaginal tape (TVT) for surgical treatment of stress urinary incontinence. Int Urogynecol J Pelvic Floor Dysfunct 9(4):210-213 